Pengaruh Struktur Kepemilikan .... (Evy Sumartha)

\title{
PENGARUH STRUKTUR KEPEMILIKAN TERHADAP KEBIJAKAN DIVIDEN PADA PERUSAHAAN MANUFAKTUR
}

\author{
Evy Sumartha \\ Universitas Sebelas Maret Surakarta, Indonesia \\ Email:vii_sumartha@yahoo.com
}

\begin{abstract}
Abstrak: Pengaruh Struktur Kepemilikan Terhadap Kebijakan Dividen pada Perusahaan Manufaktur. Struktur kepemilikan sebagai variabel independen dalam penelitian ini diproksikan dengan kepemilikan institusional dan kepemilikan manajerial. Penelitian ini juga untuk mendapatkan bukti mengenai fungsi moderasi dari konsentrasi kepemilikan dalam hubungan antara struktur kepemilikan dan kebijakan dividen. Variabel dependen adalah kebijakan dividen yang diukur dengan Dividend Payout Ratio (DPR). Sampel yang diperoleh sebanyak 97 perusahaan selama tahun pengamatan. Pengujian hipotesis dilakukan dengan Moderating Regression Analysis dan analisis regresi data panel. Hasilnya menunjukkan bahwa konsentrasi kepemilikan berfungsi sebagai variabel moderating pada hubungan antara struktur kepemilikan dan kebijakan dividen. Untuk kepemilikan institusional pada perusahaan yang tidak mempunyai kepemilikan manajerial berpengaruh negatif terhadap Dividend Payout Ratio, sedangkan kepemilikan institusional pada perusahaan yang mempunyai kepemilikan manajerial berpengaruh positif. Kepemilikan manajerial berpengaruh positif terhadap Dividend Payout Ratio. Variabel kontrol profitabilitas dan ukuran perusahaan berpengaruh pula terhadap kebijakan dividen perusahaan.
\end{abstract}

Kata Kunci: konsentrasi kepemilikan, kepemilikan institusional, kepemilikan manajerial, ROA, ukuran perusahaan, dividend payout ratio

\begin{abstract}
Pengaruh Struktur Kepemilikan Terhadap Kebijakan Dividen pada Perusahaan Manufaktur Ownership structure; as independent variables in this research; is represented by institutional ownership and managerial ownership. This research also aimed to obtain evidence of moderation function of the concentration of ownership in the relationship between ownership structure and dividend policy. The dependent variable is dividend policy which is measured by Dividend Payout Ratio (DPR). There are 97 sample companies. Hypothesis testing is done by Moderating Regression Analysis (MRA) and panel regression analysis. The results of this research show that the concentration of ownership serves as a moderating variable on the relationship between ownership structure and dividend policy. Institutional ownership in companies that do not have a managerial ownership has a negative effect on Dividend Payout Ratio; while institutional ownership in companies that have a managerial ownership has a positive effect on Dividend Payout Ratio. Profitability and company size as a control variable has effect on dividend policy.
\end{abstract}

Keywords: the concentration of ownership, institutional ownership, managerial ownership, ROA, company size, dividend payout ratio

\section{PENDAHULUAN}

Sebagian besar investor dalam melakukan keputusan investasi memiliki tujuan; yaitu untuk memperoleh keuntungan yang

tercermin dalam besarnya tingkat
pengembalian atas investasi mereka.

Dividen yang dibagikan merupakan faktor penting yang menentukan kekayaan 
pemegang saham (Azhagaiah dan Priya; 2008). Pembagian dividen yang diharapkan oleh investor tentunya cenderung stabil bahkan meningkat dari periode sekarang ke periode selanjutnya. Kebijakan pembagian dividen yang stabil ini diharapkan dapat meningkatkan kepercayaan investor dalam mengambil keputusan investasi. Pernyataan tersebut juga didukung oleh beberapa penelitian yang telah dilakukan sebelumnya antara lain studi empiris yang dilakukan oleh Aharony dan Swary (1980); yang mengemukakan bahwa informasi yang diberikan pada saat pengumuman dividen lebih bernilai daripada pengumuman laba. Dalam hal kandungan informasi; investor juga dapat melihat dari tingkat laba periode tertentu untuk mengetahui kinerja perusahaan selain dari pembagian dividen. Pernyataan ini sesuai dengan Anderson (2009) di dalam penelitiannya yang menyebutkan adanya bukti bahwa pengungkapan dividen dan laba biasanya dilakukan dalam satu pengumuman tunggal pada sebagian besar perusahaan di Selandia Baru. Penelitian lain yang menemukan adanya kandungan informasi atas pengumuman dividen yaitu Brickley (1983); dan Koch dan Sun (2004).

Manajer seringkali menggunakan dividen untuk mengkomunikasikan informasi; salah satunya mengenai skala pendapatan perusahaan secara umum (Liu dan Chen; 2015). Sebaliknya; untuk perusahaan dengan kinerja yang tidak begitu baik akan sulit dalam mengambil keputusan pembagian dividen; sehingga sinyal dengan menggunakan dividen akan menjadi mahal (Amihud dan Li; 2002). Dalam hal ini perusahaan akan sulit membagikan dividen apabila kondisi keuangannya tidak memungkinkan; sehingga signalling theory yang terkandung dalam informasi kebijakan pembagian dividen akan menjadi sulit pula untuk dilakukan. Suatu perusahaan dengan tingkat profitabilitas yang tinggi dan merupakan perusahaan yang sudah dalam tahap mature company akan cenderung mudah untuk meningkatkan kebijakan pembagian dividen (Bulan; Subramanian; dan Tanlu; 2007). Kebijakan dividen (dividend policy) dalam praktiknya memerlukan peran manajemen perusahaan. Pada hakikatnya manajemen memiliki kekuasaan untuk pengambilan keputusan yang berkaitan dengan kegiatan perusahaan; hal ini biasanya dilakukan dengan membentuk strategy decision making (Papadakis; Lioukas; dan Chamber 1998).)

Berdasar pada teori keagenan; manajemen berperan sebagai agent atau pihak yang diberi tugas untuk mengelola perusahaan dengan baik; sedangkan pemegang saham berperan sebagai principal atau pihak yang melakukan kontrol terhadap kinerja manajemen pada perusahaan yang bersangkutan. Kebijakan pembagian dividen ini menjadi tugas manajemen untuk mengelola perusahaan dengan baik sehingga perusahaan dapat memaksimalkan keuntungan dan mampu membayar dividen kepada para pemegang saham. Menurut Bandi (2009); hubungan keagenan tersebut memberikan ruang bagi terjadinya konflik kepentingan yang terjadi antara principal dan agent. Terdapat beberapa cara yang dapat ditempuh untuk mengurangi permasalahan keagenan (agency problem) ini; sebagai contoh mendekatkan kepentingan manajemen terhadap 
kepentingan para pemegang saham atau investor dengan meningkatkan kepemilikan sahamnya pada perusahaan yang bersangkutan. Cara lain yang dapat ditempuh yaitu dengan meningkatkan kontrol terhadap kinerja manajemen melalui peningkatan kepemilikan di luar perusahaan. Kepemilikan institusional lebih mampu melakukan pengawasan terhadap manajemen perusahaan daripada kepemilikan yang menyebar dan kecil (Shleifer dan Vishny; 1986; dan Allen dan Michaely; 2001). Hal ini juga mengindikasikan bahwa adanya kepemilikan yang terkonsentrasi dapat lebih meningkatkan keputusan pemberian dividen kepada pemegang saham. Kepemilikan yang terkonsentrasi memiliki perhatian lebih terhadap pengawasan keputusan perusahaan dengan tujuan melindungi investasinya (Ullah; et al.; 2012). Konsentrasi kepemilikan menggambarkan bagaimana dan siapa saja yang memegang kendali atas keseluruhan atau sebagian besar atas kepemilikan perusahaan serta keseluruhan atau sebagian besar pemegang kendali atas aktivitas bisnis pada suatu perusahaan (Taman dan Nugroho; 2011).

Dalam hal profitabilitas dan ukuran perusahaan; penelitian yang dilakukan oleh Ferris; Sen; dan Yui (2006) menyebutkan bahwa semakin besar ukuran perusahan dan semakin tinggi rasio profitabilitas akan berpengaruh pada tingginya kebijakan pembagian dividen. Begitu pula dengan penelitian yang dilakukan oleh Bulan; et al. (2007) dan Dickens; Casey; dan Newman (2002) yang menyebutkan bahwa suatu perusahaan dengan kondisi mature dan memiliki ukuran yang lebih besar akan cenderung melakukan pembagian dividen. Kebijakan dividen dalam suatu perusahaan juga dipengaruhi oleh beberapa faktor antara lain ukuran perusahaan; growth opportunities; dan profitabilitas (Denis dan Osobov; 2008). Berdasarkan uraian latar belakang yang telah dijelaskan sebelumnya dan penelitian yang dilakukan oleh Huang dan Li (2006); Chasanah (2008); Mehrani et al. (2011); Grinstein dan Michaely (2005); Djumahir (2009); Short et al. (2002); D'Souza dan Saxena (1999); Fauz dan Rosidi (2007); Ullah; et al. (2012); Thanatawee (2013); Lucyanda dan Lilyana (2012); Rosdini (2009); Afza dan Mirza (2010);Sisca (2008); Nuringsih (2005); Mahadwarta dan Hartono (2002); Haruman (2008); Denis dan Osobov (2008); Ferris; et al. (2006); Bulan; et al. (2007); Dickens; et al. (2002); dan Kumar (2007) menunjukkan perbedaan hasil penelitian. Oleh karena itu, penelitian ini bertujuan untuk:

1. Menguji fungsi moderasi konsentrasi kepemilikan pada hubungan antara struktur kepemilikan dan kebijakan dividen.

2. Menguji hubungan antara struktur kepemilikan institusional dan kebijakan dividen pada perusahaan yang tidak memiliki kepemilikan manajerial yang terdaftar di BEI dengan profitabilitas dan ukuran perusahaan sebagai variabel kontrol.

3. Menguji hubungan antara struktur kepemilikan institusional dan kebijakan dividen pada perusahaan yang memiliki kepemilikan manajerial yang terdaftar di BEI dengan profitabilitas dan ukuran perusahaan sebagai variabel kontrol. 


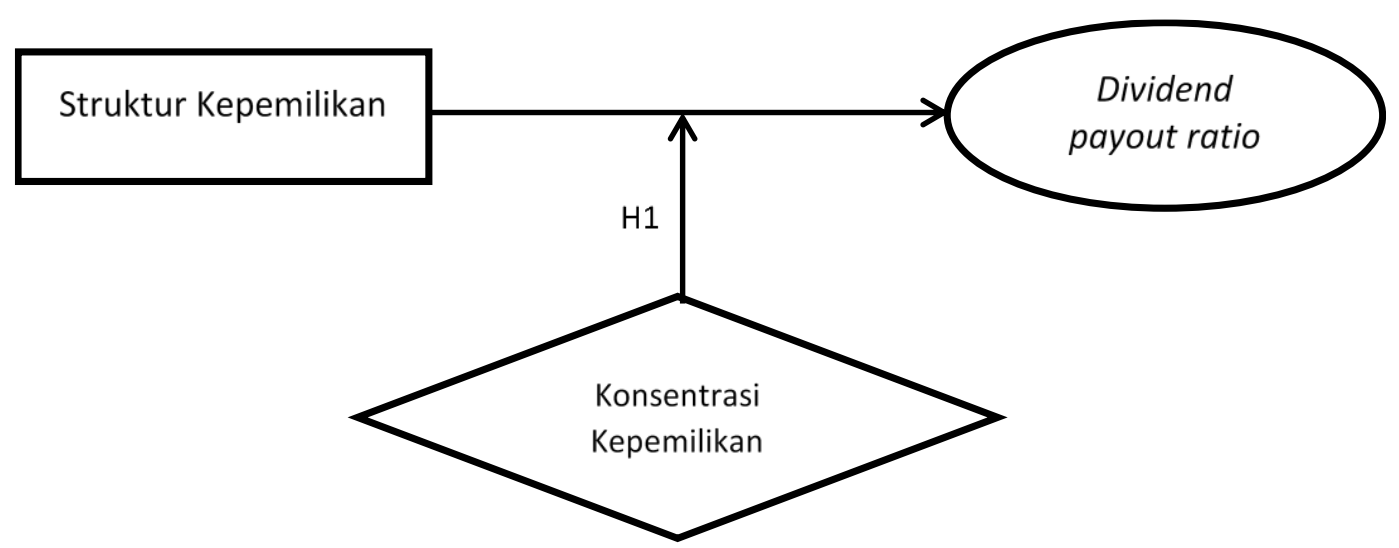

Gambar 1. Kerangka Pemikiran Penelitian

4. Menguji hubungan antara struktur kepemilikan manajerial dan kebijakan dividen pada perusahaan yang terdaftar di BEI dengan profitabilitas dan ukuran perusahaan sebagai variabel kontrol.

\section{METODE}

Gambar 1 merupakan kerangka pemikiran penelitian yang disajikan secara skematis. Kerangka pemikiran yang pertama ini dilihat dari pengaruh struktur kepemilikan terhadap kebijakan dividen dengan konsentrasi kepemilikan sebagai variabel moderating.

Selanjutnya kerangka pemikiran penelitian dikembangkan untuk melihat pengaruh struktur kepemilikan terhadap kebijakan dividen dengan melihat apakah terdapat perbedaan pada perusahaan yang terdapat kepemilikan manajerial dan yang tidak terdapat kepemilikan manajerial. Berikut kerangka pemilikan penelitian yang dibuat secara skematis.

Penelitian ini menguji mengenai struktur kepemilikan terhadap kebijakan dividen. Secara spesifik penelitian ini menguji kebijakan pembagian dividen dalam suatu perusahaan kepada para pemegang saham. Penelitian ini akan menggunakan struktur kepemilikan sebagai alat ukur untuk mengetahui pengaruhnya terhadap kebijakan dividen. Lebih lanjut penelitian ini menggunakan dua variabel kontrol untuk menguji pengaruh struktur kepemilikan terhadap kebijakan dividen; yakni profitabilitas dan ukuran perusahaan. Analisis data dalam penelitian ini dilakukan dengan statistik deskriptif dan pengujian asumsi klasik serta pengujian hipotesis. Pengujian dilakukan dengan menggunakan bantuan program Eviews 7. Sebelum dilakukan analisis terhadap hipotesis terlebih dahulu melakukan analisis deskriptif dan uji asumsi klasik. Metode analisis hipotesis yang digunakan dalam penelitian ini adalah analisis regresi linier data panel. Model analisis ini memberikan gambaran mengenai gabungan observasi lintas sektoral dan data runtun waktu sehingga jumlah observasi meningkatkan derajat kebebasan dan mengurangi kolinieritas antara variabel penjelas dan kemudian akan memperbaiki estimasi ekonometri (Rahayu; 2012).

Persamaan regresi yang digunakan adalah Moderating Regression Analysis (MRA). Variabel struktur kepemilikan ini didapatkan dari metode perhitungan variabel dummy. Apabila dalam perusahaaan sampel mempunyai struktur 


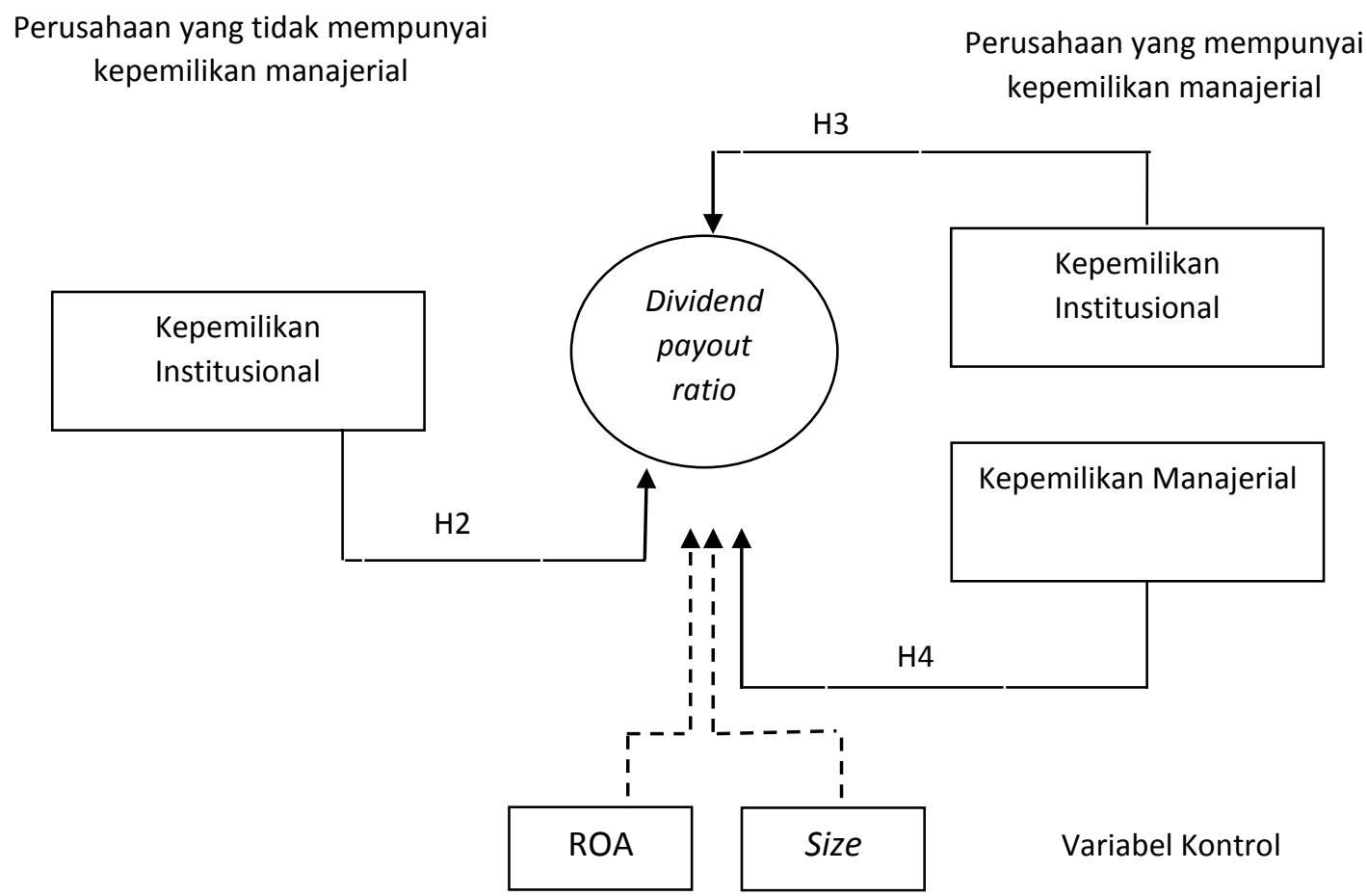

Gambar 2. Kerangka Pemikiran Penelitian

kepemilikan institusional dan manajerial maka variabel diberikan nilai 1 (satu); sedangkan untuk perusahaan sampel yang hanya memiliki kepemilikan institusional maka diberikan nilai 0 (nol).

Persamaan ini digunakan untuk mengetahui pengaruh struktur kepemilikan terhadap kebijakan dividen dengan konsentrasi kepemilikan sebagai variabel moderating; selanjutnya dapat dituliskan sebagai berikut.

$$
\begin{aligned}
& \mathrm{DPR}_{\mathrm{it}}=\beta_{0}+\beta_{1} \mathrm{SKM}_{1 \mathrm{it}}+\varepsilon \\
& \mathrm{DPR}_{\mathrm{it}}=\beta_{0}+\beta_{1} \mathrm{SKM}_{1 \mathrm{it}}+\beta_{2} \mathrm{TOP}_{2 \mathrm{it}}+\varepsilon
\end{aligned}
$$

Keterangan:

DPR : Dividend payout ratio

STK : Struktur Kepemilikan

TOP : Konsentrasi kepemilikan

B : Koefisien Korelasi

E : Error.

Persamaan regresi data panel digunakan untuk mengetahui pengaruh kepemilikan institusional terhadap kebijakan dividen pada perusahaan yang tidak mempunyai kepemilikan manajerial. Pada persamaan ini perhitungan variabel kepemilikan dengan menggunakan rasio seperti yang telah dijelaskan sebelumnya. Persamaan regresi tersebut dapat dituliskan seperti berikut ini. $D_{P R}{ }_{i t}=\beta_{0}+\beta_{1} I N S T_{1 i t}+\beta_{2}$ PROF $_{2 i t}+\beta_{3}$ SIZE $_{3 i \mathrm{t}}+\boldsymbol{e}$

Persamaan regresi data panel selanjutnya juga digunakan untuk mengetahui pengaruh struktur kepemilikan terhadap kebijakan dividen. Pada persamaan ini perhitungan variabel kepemilikan dengan menggunakan rasio seperti yang telah dijelaskan sebelumnya.

Persamaan tersebut dapat dituliskan sebagai berikut.

$D P R_{i t}=\beta_{0}+\beta_{1} I_{N S T}{ }_{1 i t}+\beta_{2} M$ MNJ $_{2 i t}+\beta_{3} P_{R O F}{ }_{3 i t}$

$+t \beta_{4}$ SIZE4 $_{\text {it }}+\varepsilon$

Keterangan:

DPR : Dividend payout ratio;

INST : Kepemilikan Institusional;

MANJ : Kepemilikan Manajerial;

PROF : Profitabilitas;

Size : Ukuran Perusahaan;

$\beta \quad$ : Koefisien Korelasi; dan

$\varepsilon \quad:$ Error 
Tabel 1. Jumlah Data Penelitian

\begin{tabular}{lc}
\hline \multicolumn{1}{c}{ Kelompok } & Jumlah \\
\hline Perusahaan yang tidak terdapat kepemilikan manajerial & $57 \times 3$ tahun $=171$ \\
Perusahaan yang terdapat kepemilikan manajerial & $40 \times 3$ tahun $=120$ \\
\hline
\end{tabular}

\section{HASIL DAN PEMBAHASAN}

Penelitian ini menggunakan data sekunder berupa financial report perusahaanperusahaan yang terdaftar dalam Bursa Efek Indonesia pada tahun 2012 - 2014. Data diambil dari website resmi BEI (www.idx.go.id) dan Indonesian Capital Market Directory (ICMD) untuk tahun yang bersangkutan. Teknik pengambilan sampel menggunakan metode purposive sampling dan pengamatan dilakukan dengan metode time series untuk setiap sampel yang akan digunakan. Dari total 97 sampel dapat dijabarkan secara rinci yaitu 57 sampel untuk perusahaan yang tidak terdapat kepemilikan manajerial dan 40 perusahaan yang terdapat kepemilikan manajerial.

Untuk analisis deskriptif yang dilakukan untuk setiap variabel penelitian ini didapatkan hasil bahwa terjadi kenaikan dan penurunan yang fluktuatif bagi setiap variabel tersebut. Untuk uji asumsi klasik; variabel telah memenuhi seluruh syarat pengujian asumsi klasik sehingga uji hipotesis dapat dilakukan secara efektif. Berikut penjabaran dari hasil pengujian hipotesis yang dilakukan.
Hipotesis pertama penelitian ini adalah adanya konsentrasi kepemilikan perusahaan sekarang berfungsi sebagai variabel moderating pada pengaruh struktur kepemilikan terhadap kebijakan dividen mendatang. Peneliti mengembangkan hipotesis pertama ini dengan fokus untuk mengetahui pengaruh konsentrasi kepemilikan secara moderating baik pada perusahaan yang memiliki struktur kepemilikan institusional maupun manajerial. Hubungan antara konsentrasi kepemilikan sekarang sebagai variabel moderating pada pengaruh antara struktur kepemilikan terhadap kebijakan dividen mendatang dapat dinyatakan dalam rumus regresi seperti di bawah ini.

DPRt+1 $=\beta_{0}+\beta_{1} \mathrm{SKM}_{1 \mathrm{it}}+\varepsilon$

DPRt $+1=\beta_{0}+\beta_{1} \mathrm{SKM}_{1 \mathrm{it}}+\beta_{2} \mathrm{TOP}_{2 \mathrm{it}}+\varepsilon$

Peneliti telah melakukan uji asumsi klasik sebelum melakukan uji hipotesis pertama ini dengan tujuan untuk menentukan apakah data variabel yang digunakan telah terdistribusi secara normal; terbebas dari problem autokorelasi; dan tidak terjadi multikolinieritas. Penjelasan mengenai uji asumsi klasik tersebut dapat dilihat pada tabel-tabel pengujian asumsi klasik yang

Tabel 2. Hasil Uji Hipotesis 1 Sebelum Moderating Regression Analysis (MRA)

\begin{tabular}{lccc}
\hline \multicolumn{1}{c}{ Variabel } & Koefisien & T & Sig. \\
\hline Konstanta & 14,853 & 17,355 & 0,000 \\
Struktur Kepemilikan (INST) & 0,479 & 0,360 & 0,719 \\
R Square = 0,0004 & & & \\
Adjusted R Square $=0,003$ & & & \\
${ }^{*}$ Signifikan 5\% & & & \\
\hline
\end{tabular}


Tabel 3. Hasil Uji Hipotesis 1 Setelah Moderating Regression Analysis (MRA)

\begin{tabular}{lccc}
\hline \multicolumn{1}{c}{ Variabel } & Koefisien & T & Sig. \\
\hline Konstanta & 33,079 & 10,796 & 0,000 \\
Struktur Kepemilikan (SKM) & $-4,508$ & $-2,002$ & 0,046 \\
Konsentrasi Kepemilikan (TOP) & 0,001 & 0,026 & 0,979 \\
R Square = 0,69945 & & & \\
Adjusted R Square =0,053 & & & \\
${ }^{*}$ Signifikan 5\% & & & \\
\hline
\end{tabular}

telah dilakukan sebelumnya. Pengujian asumsi klasik tersebut dilakukan dengan tujuan untuk mendapatkan data yang baik; sehingga terbebas dari bias.

Berdasarkan Tabel 2 dan 3 tersebut dapat dituliskan persamaan regresi untuk hipotesis 1 sebagai berikut.

$$
\begin{aligned}
& \mathrm{DPR}_{\mathrm{it}}=14,853+0,479+\varepsilon \\
& \mathrm{DPR}_{\mathrm{it}}=33,079+0,001-4,508+\varepsilon
\end{aligned}
$$

Dari hasil analisis tersebut pembahasan akan berfokus pada pengaruh konsentrasi kepemilikan secara moderating dalam hal pengaruh struktur kepemilikan terhadap dividend payout ratio. Apabila dilihat dari nilai R-Square nya sebelum dilakukan Moderating Regression Analysis (MRA) adalah 0,0004 kemudian setelah dilakukan analisis MRA nilai R-Square nya 0,69945. Kenaikan nilai dari R-Square ini menunjukkan bahwa variabel konsentrasi kepemilikan merupakan variabel moderating dalam mempengaruhi hubungan antara struktur kepemilikan terhadap kebijakan dividen. Namun apabila dilihat dari tingkat signifikansi yang lebih dari 0,05 maka hubungan dalam persamaan ini cenderung tidak signifikan. Dengan demikian; dapat dikatakan hipotesis pertama yang menyatakan konsentrasi kepemilikan berfungsi sebagai variabel moderating dalam pengaruh struktur kepemilikan terhadap kebijakan dividen diterima; (Ho ditolak).
Hasil ini sejalan dengan penelitian yang dilakukan oleh Thanatawee (2013) yang menyatakan bahwa konsentrasi kepemilikan dapat lebih berpengaruh terhadap keputusan pembagian dividen. Kepemilikan yang terkonsentrasi akan memiliki perhatian yang lebih terhadap pengawassan keputusan perusahaan untuk melindungi investasinya (Ullah; et al; 2012).

Hipotesis kedua dalam penelitian ini adalah struktur kepemilikan institusional sekarang berpengaruh positif pada dividend payout ratiomendatang. Peneliti mengembangkan hipotesis kedua ini dengan fokus perusahaan sampel yang sahamnya tidak dimiliki oleh manajemen atau yang tidak terdapat kepemilikan manajerial di dalamnya. Hubungan antara struktur kepemilikan institusional sekarang dengan dividen mendatang dapat dinyatakan dalam rumus regresi seperti di bawah ini.

\section{$D P R_{i t}=\beta_{0}+\beta_{1} I_{N S T}{ }_{1 i t}+\beta_{2} P_{R O F}{ }_{2 i t}+\beta_{3} S_{I Z E} E_{3 i t}+e$}

Peneliti telah melakukan uji asumsi klasik sebelum melakukan uji hipotesis pertama ini dengan tujuan untuk menentukan apakah data variabel yang digunakan telah terdistribusi secara normal dan terbebas dari problem autokorelasi. Penjelasan mengenai uji asumsi klasik tersebut dapat dilihat pada tabel-tabel pengujian asumsi klasik yang telah dilakukan sebelumnya. Pengujian asumsi klasik tersebut dilakukan dengan 
Tabel 4. Hasil Uji Regresi Hipotesis 2

\begin{tabular}{lccc}
\hline \multicolumn{1}{c}{ Variabel } & Koefisien & t & Sig. \\
\hline Konstanta & 14,981 & 0,830 & 0,407 \\
Kepemilikan Institusional (INST) & $-0,048$ & $-0,642$ & 0,521 \\
Return On Assets (ROA) & 0,438 & 3,440 & 0,007 \\
Ukuran Perusahaan (Size) & 1,051 & 0,975 & 0,330 \\
R Square = 0,69 & & & \\
Adjusted R Square =0,05 & & & \\
${ }^{*}$ Signifikan 5\% & & & \\
\hline
\end{tabular}

tujuan untuk mendapatkan data yang baik; sehingga terbebas dari bias. Selanjutnya; setelah dilakukan analisis regresi maka didapatkan hasil seperti tabel di bawah ini.

Berdasarkan Tabel 4 dapat dituliskan persamaan regresi untuk hipotesis 2 sebagai berikut.

DPR $_{\text {it }}=14,981-0,048$ INST+ 0,438 PROF+ 1,051 SIZE+e

Persamaan regresi tersebut mempunyai makna bahwa variabel kepemilikan institusional memiliki pengaruh negatif terhadap dividend payout ratio sebesar 0,048 (angka pakai koma). Tanda koefisien negatif pada variabel kepemilikan institusional menunjukkan bahwa semakin besar proporsi kepemilikan institusional dalam perusahaan maka akan semakin kecil pula dividen yang dibagikan kepada para pemegang saham. Hal ini dapat dikarenakan memang adanya posisi kepemilikan institusional dalam perusahaan akan memberikan fungsi pengawasan dari pihak luar. Namun hal ini tetap akan menimbulkan konflik keagenan dikarenakan tidak adanya kesejajaran kepentingan dari para pemegang saham dengan manajerial perusahaan. Oleh karena itu; hubungannya masih menjadi negatif karena proporsi struktur kepemilikan institusional saja yang ada dalam suatu perusahaan tersebut. Kontrol yang efektif oleh porsi kepemilikan institusional dapat menjadi terhambat karena adanya asimetri informasi dalam perusahaan. Pada pembahasan teori keagenan juga dapat dilihat bahwa pada saat perusahaan hanya memiliki kepemilikan manajerial maka dapat memberikan pengaruh yang negatif terhadap kebijakan pembagian dividennya. Lebih lanjut mengenai hasil penelitian apabila perusahaan juga menempatkan kepemilikan manajerial dalam satu struktur kepemilikan perusahaannya akan dijelaskan lebih rinci dalam hipotesis selanjutnya.

Selain itu diperoleh t-hitung sebesar 0,642 dengan nilai signifikansi sebesar 0,521 yang lebih besar dari tingkat signifikansi yang ditetapkan sebelumnya yaitu 0,05 . Dengan demikian; hipotesis altenatif satu yang menyebutkan terdapat pengaruh antara variabel kepemilikan institusional terhadap dividend payout ratio tidak diterima; (Ho tidak ditolak). Berdasarkan tingkat signifikansi diperoleh hasil bahwa pengaruh variabel kepemilikan institusional tidak signifikan terhadap Dividend Payout Ratio. Hasil uji hipotesis pertama ini konsisten dengan penelitian sebelumnya yang dilakukan oleh Chasanah (2008) yang menyatakan bahwa kepemilikan institusional berpengaruh negatif terhadap kebijakan dividen pada perusahaan yang 
tidak terdapat kepemilikan manajerial. Sejalan pula dengan penelitian yang dilakukan oleh Grinstein dan Michaely (2005); yang menyebutkan bahwa kepemilikan institusional yang tinggi tidak berpengaruh pada kebijakan pembagian dividen pada suatu perusahaan. Namun tidak sesuai dengan penelitian yang dilakukan oleh Huang dan Li (2006); Amihud dan Li (2002); Short et al. (2002); dan Mehrani et al. (2011). Berbagai hasil penelitian itu menyebutkan bahwa terdapat pengaruh positif antara struktur kepemilikan institusional pada suatu perusahaan terhadap kebijakan dividen. Apabila dikaitkan dengan teori yang dipakai dalam penelitian ini, maka hasil hipotesis pertama ini cenderung pada Tax Preference Theory. Para pemegang saham lebih menyukai pembagian dividen yang rendah; sesuai dengan tanda koefisien negatif yang berarti bertambahnya kepemilikan institusional tidak diikuti oleh bertambahnya dividen yang dibagikan. Hal ini dikarenakan adanya pajak yang dikenakan pada setiap pembagian dividen akan menjadi lebih besar apabila terjadi kenaikan dividen yang dibagikan.

Untuk hasil dari variabel kontrol yang digunakan dalam penelitian yaitu profitabilitas dan ukuran perusahaan dapat dijelaskan seperti berikut ini. Berdasarkan pada persamaan regresi tesebut dapat dimaknai bahwa profitabilitas yang dalam hal ini diproksikan dengan ROA memiliki pengaruh positif terhadap dividend payout ratio sebesar 0,438 . Tanda koefisien positif pada variabel ROA menunjukkan bahwa semakin besar profitabilitas yang dapat dihasilkan oleh suatu perusahaan maka akan memberikan pengaruh pada semakin besarnya dividen yang dibagikan kepada para pemegang saham. Pengaruh ini juga dapat dikatakan signifikan apabila dilihat dari nilai signifikansi yaitu 0,0007 atau kurang dari 0,05. Hal ini sejalan dengan penelitian terdahulu yang dilakukan oleh Ferris; et al. (2006) yang menyebutkan bahwa adanya tingkat profitabilitas lebih tinggi yang dapat dihasilkan oleh perusahaan maka akan lebih tinggi pula dividen yang akan diberikan oleh para pemegang saham. Suatu perusahaan dalam memutuskan kebijakan pembagian dividen salah satunya dapat dipengaruhi oleh kapasitas perusahaan dalam menghasilkan laba (Denis dan Osobov; 2008). Pada ukuran perusahaan; persamaan regresi tesebut mempunyai makna bahwa ukuran perusahaan memiliki pengaruh positif terhadap dividend payout ratio sebesar 1,051 . Tanda koefisien positif pada ukuran perusahaan menunjukkan bahwa semakin besar ukuran perusahaan maka akan memberikan pengaruh pada semakin besarnya dividen yang dibagikan kepada para pemegang saham. Namun pengaruh ini tidak menunjukkan hasil yang signifikan karena berada pada tingkat signifikansi yang lebih dari 0,05 yaitu 0,33 .

Hal ini dapat dikarenakan ukuran suatu perusahaan yang lebih besar akan mengakibatkan perusahaan memiliki kemampuan lebih besar pula untuk membayarkan dividen pada pemegang saham. Sehingga hal ini berpengaruh kepada pembagian dividen pada perusahaan sampel. Hal ini sejalan dengan penelitian yang dilakukan oleh Cornett; et al. (2011) bahwa perusahan dengan ukuran lebih besar akan cenderung memberikan inisiasi 
Tabel 5. Hasil Uji Regresi Hipotesis 3 dan Hipotesis 4

\begin{tabular}{lccc}
\hline \multicolumn{1}{c}{ Variabel } & Koefisien & $\mathrm{t}$ & Sig. \\
\hline Konstanta & $-162,427$ & $-2,137$ & 0,034 \\
Kepemilikan Institusional (INST) & 0,944 & 2,152 & 0,033 \\
Kepemilikan Manajerial (MANJ) & 2,210 & 2,064 & 0,041 \\
Return On Assets (ROA) & 1,225 & 1,299 & 0,196 \\
Ukuran Perusahaan (Size) & 8,132 & 2,019 & 0,045 \\
\hline R Square = 0,06 & & & \\
Adjusted R Square $=0,03$ & & & \\
*Signifikan 5\% & & & \\
\hline
\end{tabular}

pembagian dividen yang tinggi. Namun pengaruh yang tidak signifikan dapat pula diakibatkan oleh adanya kebutuhan dana untuk investasi kembali pada perusahaan yang memiliki ukuran lebih besar. Secara umum dapat dikatakan bahwa variabel profitabilitas dan ukuran perusahaan dapat mempengaruhi suatu perusahan dalam memberikan keputusan pembagian dividen kepada para pemegang sahamnya.

Selanjutnya peneliti ingin mengembangkan kerangka pemikiran yang tertuang dalam hipotesis pertama yang berfokus pada perusahaan yang tidak terdapat kepemilikan manajerial. Peneliti kemudian ingin membuktikan bagaimana struktur kepemilikan institusional dan kepemilikan manajerial sekarang berpengaruh pada dividen per saham mendatang pada perusahaan yang terdapat kepemilikan manajerial. Hubungan yang terjadi dalam hipotesis kedua ini dapat dinyatakan seperti rumus berikut.

DPR $_{i t}=\beta_{0}+\beta_{1}$ INST $_{1 \mathrm{it}}+\beta_{2}$ MANJ $_{2 \mathrm{it}}+\beta_{3}$ PROF $_{3 \mathrm{it}}$ $+t \beta_{4}$ SIZE $_{\text {it }}+\varepsilon$

Peneliti telah melakukan uji asumsi klasik sebelum melakukan uji hipotesis pertama ini dengan tujuan untuk menentukan apakah data variabel yang digunakan telah terdistribusi secara normal; terbebas dari problem heterokedastisitas; autokorelasi; dan multikolinieritas. Hal ini dapat dilihat pada tabel-tabel pengujian asumsi klasik yang telah dilakukan sebelumnya. Setelah dilakukan analisis regresi maka didapatkan hasil seperti pada Tabel 5.

Berdasarkan Tabel 5 dapat dituliskan persamaan regresi sebagai berikut.

$D P R_{\text {it }}=-162,42+0,944$ INST + 2,210 MANJ +

\section{1,225 ROA + 8,132 SIZE}

Selanjutnya penjelasan mengenai hasil uji regresi untuk setiap hipotesis yang dikembangkan oleh peneliti sebagai berikut. Persamaan regresi tersebut mempunyai makna bahwa variabel independen pertama yaitu kepemilikan institusional memiliki pengaruh positif terhadap dividend payout ratio sebesar 0,944 . Tanda koefisien positif pada variabel kepemilikan institusional menunjukkan bahwa semakin besar proporsi kepemilikan institusional dalam perusahaan maka akan semakin besar dividen yang dibagikan kepada para pemegang saham. Pada dasarnya bahwa kepemilikan institusional memiliki fungsi pengendalian dari pihak luar. Oleh karena itu; semakin besar pengendalian yang dilakukan oleh pihak luar memberikan pengaruh pada kinerja dari perusahaan akan semakin baik; yang diharapkan dividen yang akan 
dibagikan juga akan semakin besar (Moh'd et al.; 1998). Selain itu diperoleh hasil t-hitung sebesar 2,152 dengan nilai signifikansi sebesar 0,033 yang lebih kecil dari tingkat signifikansi yang ditetapkan sebelumnya yaitu 0,05. Hal tersebut menunjukkan variabel kepemilikan institusional memiliki pengaruh yang signifikan terhadap Dividend Payout Ratio (DPR).Dengan demikian; dapat dikatakan hipotesis alternatif kedua yang menyatakan variabel kepemilikan institusional berpengaruh pada variabel dividend payout ratio diterima; (Ho ditolak).

Hasil uji hipotesis kedua ini tidak sesuai dengan penelitian yang dilakukan oleh penelitian D'Souza dan Saxena (1999); Fauz dan Rosidi (2007); Sisca (2008); dan Grinstein dan Michaely (2003) yang menyatakan bahwa bertambahnya kepemilikan institusional tidak berpengaruh terhadap kebijakan dividen. Namun sesuai dengan penelitianyang dilakukan oleh Chasanah (2008) yang menyebutkan bahwa kepemilikan institusional berpengaruh positif terhadap kebijakan dividen pada perusahaan yang sebagian sahamnya dimiliki oleh manajemen. Hasil ini juga sejalan dengan hasil penelitian Huang dan Li (2006); Amihud dan Li (2002); Short et al. (2002); dan Mehrani et al. (2011). Apabila dikaitkan dengan teori yang dipakai dalam penelitian ini; maka hasil hipotesis pertama ini cenderung pada Bird In Hand Theory. Para pemegang saham lebih menyukai pembagian dividen yang tinggi; sesuai dengan tanda koefisien positif yang berarti bertambahnya kepemilikan institusional akan diikuti oleh bertambahnya dividen yang dibagikan. Selanjutnya berdasarkan teori keagenan yang telah dijelaskan sebelumnya; bahwa apabila terdapat kesejajaran antara kepentingan manajer dan pemegang saham akan dapat mempengaruhi salah satunya dalam pengambilan kebijakan dividen perusahaan. Hasil ini berbeda dengan sebelumnya pada perusahaan yang tidak memiliki kepemilikan manajerial. Setelah penelitian dilakukan pada perusahaan yang juga memiliki kepemilikan manajerial didapatkan hasil yang positif pada pengaruh struktur kepemilikan institusional terhadap kebijakan dividen.

Ini membuktikan bahwa benar cara yang dapat digunakan untuk mengatasi teori keagenan adalah dengan meningkatkan kepemilikan manajerial dalam suatu perusahaan. Hal tersebut dapat memberikan motivasi kepada para manajer untuk dapat meningkatkan kinerja perusahaan. Pada akhirnya akan menyelaraskan kepentingan untuk mensejahterakan pemegang saham yang sekaligus dapat dirasakan oleh manajer yang bersangkutan.

Berdasarkan persamaan regresi tersebut; variabel independen kedua yaitu kepemilikan manajerial memiliki makna adanya pengaruh positif terhadap Dividend Payout Ratio (DPR) sebesar 2,210 Tanda koefisien positif pada variabel kepemilikan manajerial menunjukkan bahwa semakin besar proporsi kepemilikan manajerial dalam perusahaan maka akan semakin besar dividen yang dibagikan kepada para pemegang saham dan sebaliknya. Selain itu diperoleh t-hitung sebesar 2,064 dengan nilai signifikansi sebesar 0,041 yang lebih kecil dari tingkat signifikansi yang ditetapkan sebelumnya yaitu 0,05. Dengan demikian; hipotesis alternatif ketiga yang menyatakan bahwa variabel kepemilikan manajerial 
berpengaruh pada variabel dividend payout ratio diterima; (Ho ditolak). Hasil uji hipotesis ketiga ini sesuai dengan penelitian yang dilakukan oleh Fauz dan Rosidi (2007); dan Nuringsih (2005); dan Kumar (2007) yang menyatakan bahwa kepemilikan manajerial berpengaruh positif terhadap kebijakan dividen. Namun tidak sejalan dengan Chen dan Dhiensiri (1999); Moh'd et al. (1995); dan Rozeff (1982).

Berdasarkan penjelasan tersebut; hasil penelitian ini dapat disebabkan oleh adanya kesejajaran kepentingan dari para memegang saham dan pihak manajerial yang ikut terlibat dalam kepemilikan saham dalam perusahaannya. Sehingga hal ini dapat berpengaruh pada besarnya dividen yang dibayarkan oleh perusahaan. Hasil ini juga mendukung pendapat Jensen dan Meckling (1976) yang menyatakan bahwa cara yang dapat digunakan untuk mengatasi masalah dalam teori keagenan adalah dengan menambah proporsi kepemilikan manajerial guna menjalankan fungsi pengendalian bagi manajemen perusahaan. Selain itu dapat pula dengan mensejajarkan kepentingan manajemen dengan pemegang saham yaitu dengan menambah kepemilikan manajerial pada perusahaan yang bersangkutan. Jadi; secara bersama-sama kepemilikan institusional dan kepemilikan manajerial akan mempengaruhi kebijakan dividen sesuai dengan fungsinya dalam rangka mengatasi masalah keagenan. Selanjutnya; mengenai hasil dari perhitungan variabel kontrol yaitu profitabilitas dan ukuran perusahaan dapat dituliskan seperti berikut ini. Persamaan regresi pada variabel ROA didapatkan pengaruh yang positif dalam hubungannya dengan pembagian dividen.
Tanda koefisien positif ini dapat diartikan bahwa semakin besar tingkat profitabilitas yang didapatkan oleh perusahaan maka akan semakin besar pula dividen yang dibagikan. Dari sisi tingkat signifikansi didapatkan hasil perhitungan sebesar 0,196 yang lebih besar dari 0,05. Hal ini menunjukkan bahwa pengaruh ROA terhadap pembagian dividen cenderung tidak signifikan. Selanjutnya; persamaan regresi pada variabel ukuran perusahaan didapatkan pengaruh yang positif dalam hubungannya dengan pembagian dividen. Tanda koefisien positif ini dapat diartikan bahwa semakin besar ukuran perusahaan maka akan semakin besar pula dividen yang dibagikan. Dari sisi tingkat signifikansi didapatkan hasil perhitungan sebesar 0,045 yang lebih kecil dari 0,05. Hal ini menunjukkan bahwa pengaruh ukuran perusahaan terhadap pembagian dividen cenderung signifikan. Secara umum dapat dikatakan bahwa variabel kontrol yaitu profitabilitas dan ukuran perusahaan dapat menjadi faktor yang mempengaruhi kebijakan dividen. Hal ini sesuai dengan penelitian yang dilakukan oleh Denis dan Osobov (2008); dan Cornett; et al. (2011.

\section{SIMPULAN}

Konsentrasi kepemilikan berfungsi sebagai variabel moderating dalam hubungan antara struktur kepemilikan dengan kebijakan dividen. Hal ini menunjukkan bahwa adanya konsentrasi kepemilikan dalam suatu perusahaan dapat memberikan pengaruh baik memperkuat atau memperlemah hubungan antara struktur kepemilikan dengan kebijakan dividen. Dalam penelitian ini dapat dikatakan bahwa variabel 
konsentrasi kepemilikan memperkuat hubungan antara struktur kepemilikan terhadap kebijakan dividen. Hal tersebut dapat disebabkan oleh posisi kepemilikan yang semakin terkonsentrasi akan memberikan pengaruh yang kuat pada kebijakan penentuan pembagian dividen.

Kepemilikan Institusional berpengaruh negatif terhadap kebijakan dividen pada perusahaan yang tidak terdapat kepemilikan manajerial. Hal ini menunjukkan bahwa semakin besar proporsi kepemilikan institusional dalam perusahaan maka akan semakin kecil dividen yang dibagikan kepada para pemegang saham. Hal tersebut dapat disebabkan oleh karena porsi kepemilikan institusional akan memberikan pengaruh pada pengendalian dari pihak luar dan menjadi terhambat dengan adanya informasi yang asimetri. Hubungan ini lebih lanjut dijelaskan dalam teori keagenan bahwa adanya ketidakselarasan hubungan antara kepentingan manajer dan pemegang saham. Akhirnya; hal tersebut dapat memberikan pengaruh yang negatif dalam hubungan antara kepemilikan instritusioanl terhadap kebijakan dividen pada perusahaan yang tidak memiliki kepemilikan manajerial.

Kepemilikan Institusional berpengaruh positif terhadap kebijakan dividen pada perusahaan yang memiliki kepemilikan manajerial. Hal ini membuktikan bahwa benar cara yang dapat digunakan untuk mengatasi konflik keagenan salah satunya adalah dengan memberikan porsi kepemilikan manajerial dalam suatu perusahaan. Adanya kepemilikan institusional yang menjalankan fungsi sebagai pengawasan kinerja manajemen dari pihak luar dan porsi kepemilikan manajerial yang juga sebagai pemegang saham perusahaan akan memberikan dampak positif dalam hubungan keduanya. Hal ini dikarenakan informasi asimetri dalam perusahaan yang bersangkutan dapat diminimalkan.

Kepemilikan Manajerial berpengaruh positif terhadap kebijakan dividen. Hasil ini menunjukkan bahwa semakin besar proporsi kepemilikan manajerial dalam perusahaan akan diikuti dengan makin besarnya dividen yang dibagikan kepada para pemegang saham dan demikian sebaliknya; manajemen yang juga sebagai pemegang saham tentunya akan berperan untuk memaksimalkan kinerja perusahaan dan kepentingan mereka sekaligus sebagai pemegang saham. Apabila suatu perusahaan tersebut memiliki kinerja yang baik maka diharapkan kebijakan pembagian dividen juga akan lebih besar.

Variabel kontrol dalam penelitian ini; yakni tingkat profitabilitas dan ukuran perusahaan dapat dikatakan sebagai faktor yang dapat mempengaruhi kebijakan dividen pada perusahaan yang bersangkutan. Adanya perusahaan yang dapat menghasilkan profitabilitas lebih besar akan lebih mudah untuk menentukan kebijakan pembagian dividen. Begitu pula pada perusahaan yang memiliki ukuran yang lebih besar; cenderung lebih mudah perusahaan yang dapat menghasilkan profitabilitas lebih besar akan lebih mudah untuk menentukan kebijakan pembagian dividen.

\section{DAFTAR PUSTAKA}

Afza, T. dan H. H. Mirza. (2010). Ownership Structure and Cash Flows As Determinants of Corporate Dividend 
Policy in Pakistan. International Business Research. 3(3), 210-221.

Aharony, J. \& I. Swary. (1980). Quarterly Dividend and Earnings Announcements and Stockholders Returns: An Empirical Analysis. The Journal of Finance. 35(1), 112.

Allen, F.; dan R. Michaely. (2001). Payout Policy. Working Paper. The Wharton School.

Amihud, Y.; dan K. Li. (2002). The Declining Information Content of Dividend Announcements and the Effects of Institutional Holdings. Journal of Financial and Quantitative Analysis, 41(3), 637-660.

Anderson, W. (2009). Alternative Event Study Methodology for Detecting Dividend Signals in The Context of Joint Dividend and Earnings Announcements. Accounting and Finance, 49(2), 247-265.

Azhagaiah, R.; dan S. Priya. (2008). The Impact of Dividend Policy on Shareholders' Wealth. International Research Journal of Finance and Economics, 181-187.

Bandi. (2009). Kualitas Laba Dalam Perspektif Akrual-Arus Kas Dan Persinyalan Dividen. Disertasi S3 Program Pasca Sarjana UNDIP; Semarang.

Brickley, J. A. (1983). Shareholder Wealth; Information Signaling and The Specially Designated Dividend. Journal of Financial Economics, 12, 187-209.

Bulan, L.; N. Subramanian; dan L. Tanlu. (2007). On The Timing Of Dividend Initiation. Financial Management, 36(4), 31-65.

Chasanah, A.N. (2008). Faktor-Faktor Yang Mempengaruhi Dividend Payout Ratio (DPR) Pada Perusahaan Yang Listed Di Bursa Efek Indonesia (Perbandingan Pada Perusahaan Yang Sebagian
Sahamnya Dimiliki Oleh Manajemen Dan Yang Tidak Dimiliki Oleh Manajemen). Masters Thesis. Program Pasca Sarjana Universitas Diponegoro.

Chen, J.; dan N. Dhiensiri. (2009). Determinants of Dividend Policy: The Evidence from New Zealand. International Research Journal of Finance and Economics, 34, 18-28.

Cornett; M. M.; A. Fayman; A. J. Marcus; dan H. Tehranian. (2011). Dividends; Maturity; And Acquisitions : Evidence From a Sample of Bank IPOs. Review of Financial Economic, 20, 11-21.

D'Souza, J.; dan A. K. Saxena. (1999). Agency Cost; Market Risk; Investment Opportunities and Dividend Policy - An International Perspective. Managerial Finance, 25(6), 35.

Denis, D.J. dan I. Osobov. (2008). Why Do Firms Pay Dividends? International Evidence On Determinants Of Dividend Policy. Journal of Financial Economic, 89, 62-82.

Dickens, R.N.; K. M. Casey; dan J. A. Newman. (2002). Bank Dividend Policy: Explanatory Factors. Quarterly Journal of Business Economic, 41(1), 3-12.

Djumahir. (2009). Pengaruh Biaya Agensi; Tahap Daur Hidup Perusahaan; dan Regulasi terhadap Kebijakan Dividen pada Perusahaan Manufaktur di BEl. Jurnal Manajemen dan Kewirausahaan, 11(2), 144-153.

Fauz, A.; dan Rosidi. (2007). Pengaruh Aliran Kas Bebas; Kepemilikan Manajerial; Kepemilikan Institusional; Kebijakan Utang; dan Collateral Asset Terhadap Kebijakan Dividen. Jurnal Ekonomi dan Manajemen, 8(2).

Ferris, S. P.; N. Sen; dan H. P. Yui. (2006). God Save The Queen and Her Dividends: Corporate Payouts In The 
Grinstein, Y.; dan R. Michaely. (2005). Institutional Holdings and Payout Policy. The Journal of Finance, 60(3), 1389-1426.

Hartono; R. A; dan A. D. R. Atahau. 2007. Analisis Interdependensi Insider Ownership. Jurnal Ekonomi dan Bisnis, 13(1), 1-19.

Haruman, T. (2008). Pengaruh Struktur Kepemilikan Terhadap Keputusan Keuangan dan Nilai Perusahaan. Simposium Nasional Akuntansi XI; Pontianak.

Huang, G.; dan Q. Li. (2006). Influence of Institutional Ownership on Cash Dividend Policy of China Listed Companies. The Sixth Wuhan International Conference on E-Business -International Finance Track.

Jensen, M. C.; dan W. Meckling. (1976). Theory of the firm: Managerial behavior; agency costs and capital structure. Journal of Financial Economics, 3, 305360.

Koch, A. S.; dan A. X. Sun. (2004). Dividend Changes and the Persistence of Past Earnings Changes. Journal of Finance, 59(5), 2093-2116.

Kumar; S. 2007; Analisis Pengaruh Struktur Kepemilikan; Investment Opportunity Set (IOS); dan Rasio-Rasio Keuangan Terhadap DPR. Tesis. Program Pasca Sarjana Magister Manajemen Universitas Diponegoro.

Liu; C. dan A. S. Chen. (2015). Do Firms Use Dividend Changes To Signal Future Profitability? A Simultaneous Equation Analysis. International Review of Financial Analysis, 37, 194-207

Lucyanda, J. dan Lilyana. (2012). Pengaruh Free Cash Flow dan Struktur Kepemilikan terhadap Dividend Payout Ratio. Jurnal Dinamika Akuntansi. Vol. 4; No. 2; hlm. 129-138.
Mehrani, S.; M. Moradi; dan H. Eskandar. (2011). Ownership Structure and Dividend Policy: Evidence from Iran. African Journal of Business Management, 5(17), 7516-7525.

Moh'd, M. A. ; L. G. Perry; dan J. N. Rimbey. (1998). The Impact of Ownership Structure on Corporate Debt Policy: A Time-Series Cross-Sectional Analysis. The Financial Review, 33, 85-99.

Papadakis, V. M.; S. Lioukas; dan D. Chambers. (1998). Strategic DecisionMaking Processes: The Role of Management and Context. Strategic Management Journal; 19(2), 115-147.

Rahayu, S. A. T. (2012). Modul Laboratorium Ekonometrika (Dengan Aplikasi Eviews). Jurusan Ekonomi Pembangunan; Universitas Sebelas Maret.

Rosdini, Dini. (2009). Pengaruh Free Cash Flow terhadap Dividend Payout Ratio. Working Paper in Accounting and Finance. Departemen of Accounting; Padjadjaran University, 1-9.

Shleifer, A.; dan R. Vishny. (1986). Large Shareholders and Corporate Control. Journal of Political Economy; Vol. 94; hlm. 461- 488.

Short, H.; H. Zhang; dan K. Keasey. (2002). The Link between Dividend Policy and Institutional Ownership. Journal of Corporate Finance, 8, 105-122.

Sisca, C. D. (2008). Pengaruh Kepemilikan Manajerial; Kepemilikan Institusional; Kebijakan Utang; Profitabilitas; dan Ukuran Perusahaan terhadap Kebijakan Dividen. Jurnal Bisnis dan Akuntansi, 10(1),47-58.

Taman, Abdullah dan Billy; A. N. (2011). Determinan Kualitas Implementasi Corporate Governance pada Perubahan yang Terdaftar di Bursa Efek Indonesia (BEI) Periode 2004-2008. Jurnal Pendidikan Akuntansi Indonesia. 9(1). 
Jurnal Economia, Volume 12, Nomor 2, Oktober 2016

Thanatawee, Yordying. (2013). Ownership Structure and Dividend Policy: Evidence from Thailand. International Journal of Economics and Finance, 5(1), 121-132.
Ullah, H.; A. Fida; dan S. Khan. (2012). The Impact of Ownership Structure on Dividend Policy Evidence from Emerging Markets KSE-100 Index Pakistan. International Journal of Business and Social Science. 3(9), 298-307. 